\title{
Molecular Characterization of Brucella melitensis Detected from Aborted Sheep
}

\author{
Vinay Kumar*, Aman Kumar, Sushila Maan, Nitish Bansal and Trilok Nanda \\ Department of Animal Biotechnology, College of Veterinary Sciences, \\ Lala Lajpat Rai University of Veterinary and Animal Sciences, \\ Hisar-125 004, India \\ *Corresponding author
}

\section{A B S T R A C T}

Keywords

Brucella melitensis,

Sheep, Real time

PCR, Sequencing

Article Info

Accepted:

20 December 2018

Available Online:

10 January 2019
Brucellosis is one of the world's major zoonoses that affect wide range of domesticated as well as wild animals. Despite the eradication program of brucellosis, the disease is still endemic among cattle, buffaloes, sheep and goats. In many developing countries including India, Brucella melitensis is of much concern due to heavy economic losses to animal husbandry sector as well as humans. The present study was carried out to detect and characterize B. melitensis from biological samples (blood, vaginal swabs and aborted foetal material from 8 animals) collected from a disease outbreak in sheep flock using TaqMan probe based real time PCR (qPCR) assay and nucleotide sequencing. Out of 20 biological samples, $6(30 \%)$ were found positive for Brucella spp. specific and Brucella melitensis specific qPCR assay. Further B. melitensis was confirmed by sequencing of the 1343 bp of $16 \mathrm{~S}$ rRNA gene generated in conventional PCR.

\section{Introduction}

Brucellosis is a contagious, infectious and communicable disease caused by bacteria of genus Brucella, which is small, gram-negative coccobacillus (Brucellaeceae family). Besides ongoing eradication programs, brucellosis is the most widespread zoonosis that infects mainly cattle, buffalo, bison, sheep, goats, and pigs. It can transfer from animals to humans by direct contact with blood, placenta, fetuses, or uterine secretions or through consumption of infected and raw animal products (especially milk and milk products) (Gupta $e t$ al., 2006).The genus Brucella is composed of nine recognised species, out of which, six are the "classical" members (B. abortus, $B$. melitensis, B. suis, B. ovis, B. canis, $B$. neotomae) (Cutler et al., 2005).

Brucella melitensis is the main causative agent responsible for caprine and ovine brucellosis. It leads to significant financial losses in animal husbandry due to abortion and fertility problems in sheep and goats (Pappas et al., 2005; Seleem et al., 2010). The clinical manifestations of brucellosis in goat and sheep are similar to those in cattle in regards to decrease in fertility, abortion, stillbirth, decrease in milk production and reproductive 
failure (Gupta et al., 2006). B. melitensis also affects humans and causes a serious, debilitating and sometimes chronic disease that can affect a variety of organs.

Brucellosis has an important world-wide impact on animal industries and human health. Control measures are based on prevention and eradication. Although in some developed countries this disease have been eradicated by the combination of strict veterinary hygiene measures, surveillance programs and improved food safety measures, it remains endemic in large areas (Habtamu et al., 2013). Brucellosis is still an uncontrolled serious public health problem in many developing countries including India (Acha and Szyfres, 2003; Saleem et al., 2004; Minas, 2006; WHO, 2006).

The huge economic losses to animal husbandry (Singh et al., 2015) due to brucellosis in sheep and goats demand the use of sensitive and rapid diagnostic methods for proper detection and implementation of control strategies for Brucella spp. and $B$. melitensis. At present, brucellosis in goats is either diagnosed by isolation of Brucella from clinical samples or the detection of antibody in serum (Alton et al., 1988). However, these methods are not fully satisfactory and are lengthy and labour intensive and also have reduced sensitivity in chronic infections. Bacteriological isolation is time consuming and hazardous procedure as it is associated with a high risk of laboratory acquired infection (Gupta et al., 2006; Kumar et al., 2015). Serological methods are easy to perform but are inconclusive because crossreaction with other bacteria can give false negative results (Alton et al., 1988; OIE, 2009).

Nucleic acid based techniques (PCR-based) have the potential to be simple, fast, less hazardous, usually more sensitive and efficient in detecting Brucella (Bricker, 2002). Realtime PCR is rapid, fast and more sensitive over conventional PCR as real-time PCR results can be evaluated without gel electrophoresis which ultimately results in reduced experiment time and increased throughput (Kumar et al., 2015). The present study was aimed for molecular detection and characterisation of Brucella spp. from clinical samples collected during a field investigation from a flock of sheep by employing IS711 and BMEII0466 gene based real time PCR assay (Kumar et al., 2015; 2017).

\section{Materials and Methods}

\section{Collection of samples}

Blood samples, vaginal/cervical swab samples were collected aseptically from affected sheep $(\mathrm{n}=10)$ having clinical signs of brucellosis from different herds in Bure village $\left(28.9463^{\circ}\right.$ $\mathrm{N}, 75.7556^{\circ} \mathrm{E}$ ), Hisar District of Haryana. The main clinical manifestations in sheep were reproductive failures, heavy number of abortions and birth of weak offspring. Abortion generally occurred during the last 2 months of pregnancy.

\section{Extraction of genomic DNA}

Genomic DNA was extracted from collected samples by using Purelink DNA isolation kit (Invitrogen, USA) as per manufacturer's protocol. Briefly, $400 \mu 1$ of sample (blood) was taken in a $1.5 \mu 1$ sterile micro centrifuge tube. Vaginal swabs and cervical swabs were firstly dissolved in sterile PBS and then total of $400 \mu \mathrm{l}$ sample was taken in a $1.5 \mu 1$ sterile micro centrifuge tube. Then, $400 \mu 1$ of genomic lysis/binding buffer and $40 \mu \mathrm{l}$ proteinase $\mathrm{K}$ was added, mixed and incubated at $55^{\circ} \mathrm{C}$ for $30 \mathrm{~min}$ in water bath. After that $400 \mu 1$ of absolute ethanol was added in the solution and the solution was vortexed and transferred in silica based spin column. The 
spin column was centrifuged at $13000 \mathrm{rpm}$ for 2 min. After washing with $500 \mu l$ of wash

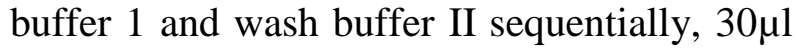
of elution buffer was added in the column and centrifuged at $13000 \mathrm{rpm}$ for $3 \mathrm{~min}$ to elute the DNA. The concentration and purity of the extracted DNA was measured spectrophotometrically (BIO-RAD, India) by measuring the wavelength at $A_{260}$ and $A_{280}$ and their purity was assessed by taking the 260/280 ratio (Sambrook and Russel, 2001). The obtained DNA was used as template in conventional PCR as well as real time PCR.

\section{Real time PCR amplification}

The extracted genomic DNA was subjected to real time PCR for amplification of Brucella spp. specific gene and Brucella melitensis specific gene using the primer and probe shown in table 1 . The real time PCR assay was performed in a total reaction volume of $25 \mu \mathrm{l}$ consisting of $12.5 \mu \mathrm{l}$ of $2 \mathrm{X}$ TaqMan Fast Universal Master Mix (ABI, USA), $1 \mu \mathrm{l}$ $(0.8 \mu \mathrm{M})$ of each forward primer, reverse primer and probe, and $4 \mu \mathrm{l}$ of extracted DNA as template. The amplification and fluorescence detection was performed on Step One Plus (ABI, USA) real time PCR system using the thermal conditions as: preheating at $50^{\circ} \mathrm{C}$ for $2 \mathrm{~min}$, initial denaturation at $95^{\circ} \mathrm{C}$ for $10 \mathrm{~min}, 40$ cycles of denaturation at $95^{\circ} \mathrm{C}$ for $15 \mathrm{sec}$, annealing and extension at $60^{\circ} \mathrm{C}$ for 1 $\min$.

\section{PCR amplification of 16S rRNA and sequence analysis}

The extracted DNA was also used in PCR (Veriti, ABI, USA) for amplification of $16 \mathrm{~S}$ rRNA gene of Brucella species using published primers as shown in table 1. The PCR assay was performed in a total reaction volume of $50 \mu \mathrm{l}$ consisting of $25 \mu \mathrm{l}$ of $2 \mathrm{X}$ High Fidelity Phusion Master Mix (NEB, UK), $2 \mu 1$ of forward and reverse primer, $2 \mu \mathrm{l}$ of DMSO, and $12 \mu \mathrm{l}$ of extracted DNA as template. The cyclic conditions used in PCR were: Initial denaturation at $98^{\circ} \mathrm{C}$ for $45 \mathrm{sec}$, and 35 cycles of denaturation at $98^{\circ} \mathrm{C}$ for 15 sec, annealing at $60^{\circ} \mathrm{C}$ for $30 \mathrm{sec}$ and elongation at $72^{\circ} \mathrm{C}$ for $30 \mathrm{sec}$ followed by final elongation at $72^{\circ} \mathrm{C}$ for $5 \mathrm{~min}$. The PCR products were run on $1.5 \%$ agarose gel, stained with ethidium bromide and visualized under gel documentation system (BIO-RAD, India). The PCR products were purified using QIAGEN gel extraction kit (USA) as per manufacturer's protocol and the purified PCR products were sequenced from both ends using forward and reverse primers in separate reaction by dideoxy chain termination method in ABI 3730 sequencer (ABI, USA).

The alignment of DNA sequences was performed by using Bioedit software along with the reference sequence of $B$. melitensis 16M. The BLAST analysis of the aligned sequences was also done to compare with other reported sequences of Brucella species.

\section{Results and Discussion}

\section{Real time PCR results}

Six samples out of twenty (30\%) were showing significant fluorescence with good $\mathrm{Ct}$ values ranging from 15 to 32 in real time PCR as shown in figure 1, indicating the presence of Brucella spp. in the clinical samples. All the six samples showing significant fluorescence with good $\mathrm{Ct}$ values ranging from 20 to 34 in real time PCR as shown in figure 2, indicating the presence of Brucella melitensis in the clinical samples. No significant fluorescence was observed in the negative control.

\section{Molecular characterization}

The PCR results for $16 \mathrm{~S}$ rRNA amplification showed amplification of $1343 \mathrm{bp}$ product with LPW primer set as shown in figure 3. No amplification was observed in negative 
control. Sequencing analysis of $16 \mathrm{~S}$ rRNA based primers was done for 2 samples using dideoxy chain termination method and the obtained sequences were aligned and matched with B. melitensis $16 \mathrm{M}$ reference sequence.
The BLAST analysis of deduced sequences of $16 \mathrm{~S}$ rRNA revealed 100 per cent similarity with 16S rRNA of Brucella melitensis 16M (biotype1).

Table.1 Primer and probe for sequencing and detection of Brucella melitensis

\begin{tabular}{|c|c|c|c|}
\hline Primer pair & Primer sequence(5'-3') & $\begin{array}{l}\text { Product size } \\
\text { (bp) }\end{array}$ & References \\
\hline BrucellaIS711 F & GACATATTCAAAGTCCGGCGTAT & \multirow{3}{*}{102} & \multirow{3}{*}{$\begin{array}{l}\text { Kumar et al., } \\
2015\end{array}$} \\
\hline BrucellaIS711 R & CAAATGGACAGCGGTTCATGC & & \\
\hline BrucellaIS711 P & VIC- CCTTTCCCATACACCGGCGTGCGACC-BHQ1 & & \\
\hline Brucella melitensis $\mathbf{F}$ & GAAAGAAGCGGCGAAATGGT & \multirow{3}{*}{78} & \multirow{3}{*}{$\begin{array}{l}\text { Kumar et al., } \\
2017\end{array}$} \\
\hline Brucella melitensis $\mathbf{R}$ & ATTGAAACTGCCGATGCGATATTG & & \\
\hline Brucella melitensis $\mathbf{P}$ & JOE-CAGCTTGCCGCCGA TCAGGGCTTTGCGCC- BHQ1 & & \\
\hline LPW F & AGTTTGATCCTGGCTCAG & \multirow[t]{2}{*}{1343} & \multirow[t]{2}{*}{ Woo et al., 2003} \\
\hline LPW R & AGGCCCGGGAACGTATTCAC & & \\
\hline
\end{tabular}

Fig.1 Amplification plot of field samples (n=6) positive with Brucella spp. specific q PCR

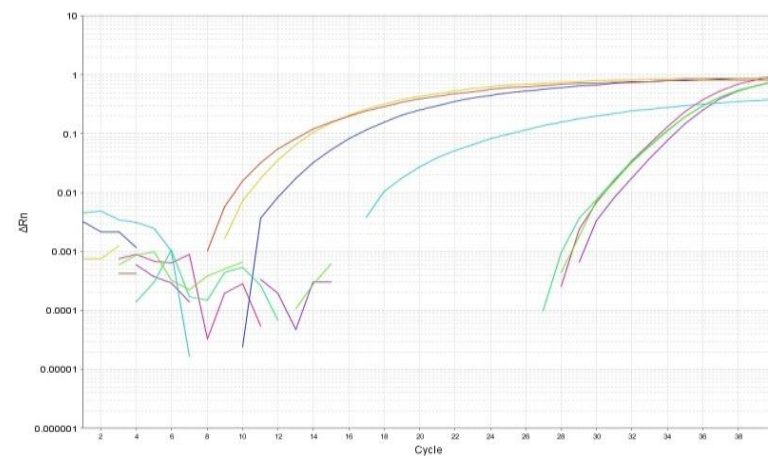

Fig.2 Amplification plot of field samples ( $\mathrm{n}=6$ ) positive with Brucella melitensis specific q PCR

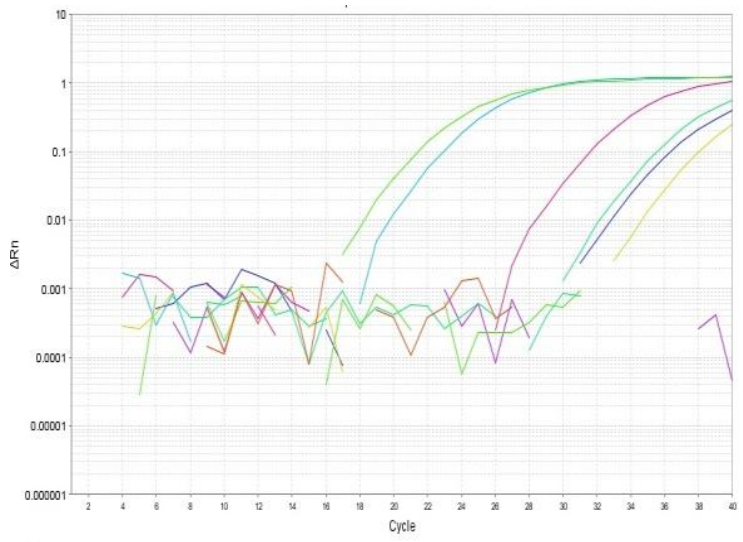


Fig.3 Agarose gel electrophoresis of conventional PCR of 16s RNA specific products generated using High Fidelity Phusion Taq DNA polymerase: L- 1 Kb DNA Ladder, 1,2,3 and 4- 1343bp band

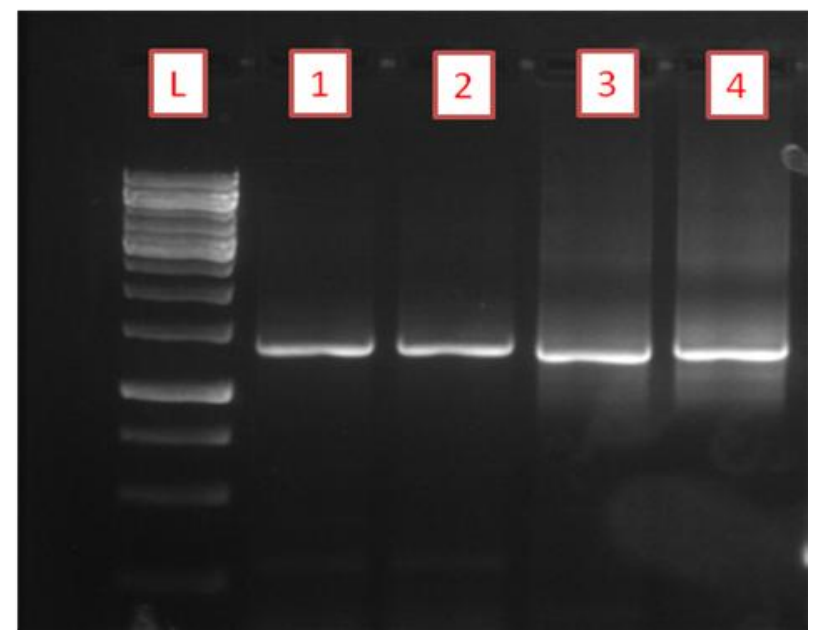

Brucellosis is still an emerging disease since the discovery of Brucella melitensis by Sir David Bruce in 1887. In tropical countries as well as in subtropical regions, Brucellosis remains the most widespread and important zoonotic disease (Gul and Khan, 2007). Identification and isolation of the bacterial species from an outbreak is essential to know the exact incidence and severity of a disease in that region and also to plan epidemiological studies, control and eradication programmes in that particular region. However, in our study, Brucella organisms were not isolated due to the fact that, Brucella culturing is hazardous, and the technique is restricted to few laboratories. Isolation rate is very low even in experienced laboratories (Wareth et al., 2014). Sometimes, there is probability of presence of few organisms in the samples or due to unhygienic sample collection procedures the sample may be heavily contaminated which reduces the chances of successful isolation of Brucella. Negative culture results may sometimes also show the infection with Brucella due to contamination (Bercovich, 1998). Also, the antibody titers against Brucella start rising by 1-2 weeks after infection which may lead to failure of early serological diagnosis from freshly aborted animals (Poester et al., 2010), therefore circulating Brucella DNA can detected earlier by molecular techniques. Thus, the diagnostic window of Brucella serology should be complemented by bacteriological or molecular diagnosis (Marianelli et al., 2008). Now a day, molecular confirmation by PCR targeting different genes has become the most common approach for early detection of bacterial isolates from an outbreak (Gee et al., 2004 and Herman and De Ridder, 1992).

In the present investigation of a suspected outbreak of ovine brucellosis, both molecular detection by real time PCR (q PCR) and sequencing procedures of the causative agent were employed. Out of a total number of 20 clinical samples of sheep subjected to nucleic acid isolation and q PCR detection, 6 (30\%) samples were found positive by IS711 based spp. identification q PCR assay (Kumar et al., 2015) and BMEII0466 (Kumar et al., 2017) gene based Brucella melitensis specific q PCR assay. 
These results are in accordance with the previous reports published by Wareth et al., 2015; Habtamu et al., 2013 and Gupta et al., 2006.

Sequence analysis of $16 \mathrm{~S}$ rRNA gene can be extensively used for molecular detection or taxonomic analysis of different bacterial species (Woo et al., 2003). It has been reported that $16 \mathrm{~S}$ rRNA gene sequencing is a reliable tool for rapid genus level identification of Brucella (Fitch et al., 1990). In this study $16 \mathrm{~S}$ rRNA gene based primers were used to produce $1343 \mathrm{bp}$ product and was sequenced. The sequence analysis of the generated products by BLAST shows $100 \%$ similarities with published sequences of Brucella melitensis. These results are in accordance with the previous studies done by Barua et al., (2016) and Habtamu et al., (2013).

Brucellosis is an important but neglected disease in India. The disease may be overlooked and misdiagnosed because of the difficult diagnosis and lack of experience with the laboratory testing. It has also been estimated that the true incidence of brucellosis may be 25 times higher than the reported incidence due to misdiagnosis and underreporting (Smith and Kadri, 2005). Therefore, to study the epidemiological surveillance, public health importance and early diagnosis of Brucella spp. the fast, reliable, sensitive and easy to perform molecular assays are urgently needed. Therefore, there is an urgent need for the strict implementation of a control policy not only for cattle but also for small ruminants. In conclusion, real time PCR based assays may be useful in early diagnosis of Brucella infection not in cattle but also in small ruminants in quick time and can replace existing lengthy and laborious laboratory tests which require skilled personnel and courage to handle the zoonotic organism.

\section{References}

Acha, N.P. and Szyfres, B. 2003. Zoonoses and communicable diseases common to man and animals. $3^{\text {rd }}$ edn. Pan American Health Organization (PAHO), Washington, DC.

Alton, G.G., Jones, L.M., Angus, R.D., Verger, J.M. 1988. Techniques for the brucellosis laboratory. Institut Nacional de la Recherche Agronomique, Paris.

Barua, A., Kumar, A., Thavaselvam, D., Mangalgi, S., Prakash, A., Tiwari, S., Arora, S. And Sathyaseelan, K. 2016. Isolation \& characterization of Brucella melitensis isolated from patients suspected for human brucellosis in India. Indian J. Med. Res. 143: 652-658.

Bercovich, Z. 1998. Maintenance of Brucella abortus- free herds: a review with emphasis on the epidemiology and the problems in diagnosing brucellosis in areas of low prevalence. Vet. Q. 20(3): 81-88.

Bricker, B.J. 2002. PCR as a diagnostic tool for brucellosis. Vet. Microbiol. 90: 435-446.

Cutler, S.J, Whatmore, A.M and Commander, N.J. 2005. Brucellosis - New aspect of an old disease. J. Appl. Microbial. 98(6): 12701281.

Fitch, T.A., Bearden, S.W., Sowa, B.A. and Marquis, H. 1990. Genetic variation at the omp2 porin locus of the brucellae: species specific markers. Mol. Microbiol. 4: 1135-1142.

Gee, J.E., De, B.K., Levett, P.N., Whitney, A.M., Novak, R.T. and Popovic, T. 2004. Use of $16 \mathrm{~S}$ rRNA genes sequencing for rapid confirmatory identification of Brucella isolates. J. Clin. Microbiol. 42: 36493654.

Gul, S.T. and Khan A. 2007. Epidemiology and Epizootology of Brucellosis: A Review. Pakistan Vet. J. 27(3): 145-151.

Gupta, V.K., Verma, D.K., Rout, P.K., Singh, S.V. and Vihan, V.S. 2006. Polymerase chain reaction (PCR) for detection of Brucella melitensis in goat milk. Small Rumin.Res. 65: 79-84.

Habtamu, T.T., Rathore, R., Dhama, K. and Karthik, K. 2013. Isolation and molecular 
detection of Brucella melitensis from disease outbreak in sheep and $B$. abortus from cattle farm by IS711 and omp $2 a$ gene based PCR. Int. J. Current. Res. 5(7): 1920-1925.

Herman, L. and De Ridder, H. 1992. Identification of Brucella spp. by using the polymerase chain reaction. Appl. Environ. Microbiol. 58: 2099-2101.

Kumar, V., Kumar, A., Debnath, A., Batra, K., Bansal, N., Gupta, A.K., Tiwari, A. and Maan, S. 2015. Development of real time PCR assay for diagnosis of Brucella spp. Haryana Vet. 54(2): 99-102.

Kumar, V., Maan, S., Kumar, A., Batra, K., Chaudhary, D., Dalal, A., Gupta, A.K., Bansal, N., Sheoran, N. and Maan, N.S. 2017. Real time PCR assay for differentiation of Brucella abortus and Brucella melitensis. Indian J. Anim. Res. doi:10.18805/ijar.v0iOF.8464.

Marianelli, C., Martucciello, A., Tarantino, M., Vecchio, R., Iovane, G. and Galiero, G. 2008. Evaluation of molecular methods for the detection of Brucella species in water buffalo milk. J. Dairy Sci. 91: 3779-3786.

Minas, A. 2006. Control and eradication of brucellosis in small ruminants. Small Rum. Res., 62: 101-107.

OIE, 2009. Terrestrial Animal Health Code Brucellosis, www.oie.int/

Pappas, G., Akritidis, N. and Tsianos, E.V. 2005. Brucellosis- Reply. New Engl. J. Med. 353(10): 1072.

Poester, F.P., Nielsen, K., Samartino, L.E. and $\mathrm{Yu}$, W.L. 2010. Diagnosis of brucellosis. Open Vet. Sci. 4: 46-60.

Saleem, A.N., Rhaymah, M.S. and Shamoon, G.N. 2004. Isolation and seroprevalence of ovine brucellosis. Iraq. J. Vet. Sci. 18: 31-38.

Sambrook, J. and Russell, D.W. 2001. Molecular cloning: A laboratory manual. ( $3^{\text {rd }}$ edn.), Cold spring harbor laboratory press, New York, USA.

Seleem, M.N., Boyle, S.M. and Sriranganathan, N. 2010. Brucellosis: a re-emerging zoonosis. Vet Microbiol. 140(3-4): 392398.

Singh, B.B., Dhand, N.K. and Gill, J.P.S. 2015. Economic losses occurring due to brucellosis in Indian livestock populations. Prev. Vet. Med. 119(3-4): 211-215.

Smith, H.L. and Kadri, S.M. 2005. Brucellosis in India: a deceptive infectious disease. Indian J. Med. Res. 122: 375-384.

W.H.O. 2006. Brucellosis in humans and animals. WHO Press, World Health Organization, Avenue Appia, Geneva, Switzerland.

Wareth, G., Hikal, A., Refai, M., Melzer, F., Roesler, U. and Neubauer, H. 2014. Animal brucellosis in Egypt. J. Infect. Dev. Ctries. 8(11): 1365-1373.

Wareth, G., Melzer, F., Tomaso, H., Roesler, U. and Neubauer, H. 2015. Detection of Brucella abortus DNA in aborted goats and sheep in Egypt by real time PCR. BMC Res. Notes 8: 212-217.

Woo, P.C.Y., Ng, K.H.L., Lau, S.K.P., Yip, K.T., Fung, A.M.Y., Leung, K.W., Tam, D.M.W., Que, T.L. and Yuen, K.Y. 2003. Usefulness of the microseq $50016 \mathrm{~s}$ ribosomal DNA-based bacterial identification system for identification of clinically significant bacterial isolates with ambiguous biochemical profiles. $J$. Clin. Microbiol. 41(5): 1996-2001.

\section{How to cite this article:}

Vinay Kumar, Aman Kumar, Sushila Maan, Nitish Bansal and Trilok Nanda. 2019. Molecular Characterization of Brucella melitensis Detected from Aborted Sheep. Int.J.Curr.Microbiol.App.Sci. 8(01): 2973-2979. doi: https://doi.org/10.20546/ijcmas.2019.801.316 